\title{
To work, to retire - or both? Labor market activity after 60
}

\author{
Mona Larsen ${ }^{1 *}$ and Peder J Pedersen ${ }^{2}$
}

\author{
* Correspondence: ml@sfi.dk \\ 'SFI - The Danish National Centre \\ for Social Research, Herluf Trolles \\ Gade 11, Copenhagen K 1052, \\ Denmark \\ Full list of author information is \\ available at the end of the article
}

\begin{abstract}
The Danish labor market follows the trend in other countries of increasing labor force participation in the 60+ group. In Denmark, this increase has - until now - been most pronounced among 60-64-year-olds and among women. Increasing labor force participation is related to both a decline in the take-up of early retirement among 60-64-yearolds, an increase in the average age of entry to a retirement program, and an increase in the propensity of working after entering a retirement program. Significant impact on work after 60 is found from education, gender, marital status, home ownership, aggregate unemployment before retirement, age and education.
\end{abstract}

JEL Codes: $\mathrm{H} 55, \mathrm{~J} 14, \mathrm{~J} 26$

Keywords: Labor force participation; Retirement

\section{照 Springer}

\section{Introduction}

In Denmark as in most other rich OECD countries the demographic prospects until the middle of the century is characterized by an increasing share of the population being 65 years and older. This perspective is the net outcome of a fairly low level of fertility in combination with an increase in longevity. On the labor market there has - until recently - been a trend towards early retirement.

These trends represent an obvious challenge to the welfare state and are the background for broad policy discussions of initiatives or instruments to increase labor force participation. One specific area is the discussion of reforms of retirement programs resulting in an increase in the average age at which older workers enter an early or a normal retirement program. Countries not succeeding in increasing labor force participation rates through reforms face a choice between welfare cuts and tax increases - or a combination of these to secure long run fiscal sustainability. The purpose of this paper is to look into other possible adaptations to the demographic prospects, i.e. the many ways in which decisions of continuing to work or not can be combined with and affected by the options included in early or normal retirement programs. Here, we focus on work either beyond the normal retirement age or after reaching potential eligibility to an early retirement program. We examine the extent of work among individuals aged 60-64 years and at least 65 years old, respectively, trends in the characteristics of those working after retirement, and gender differences in these respects. More exact knowledge about trends in paid work after retirement - a potential 4th pillar in the overall pension system - is important for policy makers in the area of pension reforms.

C 2013 Larsen and Pedersen; licensee Springer. This is an open access article distributed under the terms of the Creative Commons Attribution License (http://creativecommons.org/licenses/by/2.0), which permits unrestricted use, distribution, and reproduction in any medium, provided the original work is properly cited. 
We use Danish panel data in the analyses below. Denmark provides a useful setting for examining this topic for several reasons. First, by focusing on Denmark, we add to the fairly scarce literature about recent trends in labor force participation among older workers outside the U.S. Next, the existence of a multitude of pathways to retirement in Denmark (Larsen and Pedersen, 2008) combined with several policy changes in recent decades imply that Denmark is particular useful for studying this topic. Further, Denmark is particular suitable for the study of gender differences in work behavior at older ages because of a high labor force participation rate of women in their late fifties compared to most other OECD countries. In 2012, 74.4 percent of Danish women aged 55 to 59 years participated in the labor force compared to 57.4 percent in the OECD area as a whole (OECD, 2013). We have access to a large and rich administrative based longitudinal Danish dataset for the period 1980-2009, including annual information on income variables, together with a broad set of demographic and labor market characteristics for the whole Danish population. Finally, access to data for the whole population is particularly important in the present context, given the relatively small number of older individuals working at high ages, in particular among women.

In the next section, we present a survey of recent literature both in the more broad area of labor force participation among older people and in the more specific area of labor market activity after entry to a retirement program. In Section 3, we briefly summarize international trends in employment rates among the 60-69 years old. In Section 4, we describe recent Danish changes in policy and regulations in the pension area of relevance for this paper. Further, we show recent trends in Denmark in both the average age for entering a retirement program and the employment rate for older individuals. In Section 5, we present the results from a number of regression analyses conducted for men and women separately in which the propensity to have paid work after retirement is related to a number of background factors. Further, Section 5 presents results based on panel data of the determinants for remaining another year in the labor force for individuals potentially eligible for early retirement. Section 6 concludes the paper.

\section{Earlier studies}

In the retirement and pension literature, one of the dominant results so far has been the strong incentive impact from social security programs. A high implicit tax on continued work from a specific age has been one of the main explanations of the decline in average retirement ages, see Gruber and Wise (1999). Recently, however, a small empirical literature has treated a change in this pattern, namely an increase in labor force participation rates among individuals above the main social security retirement age. According to Komp et al. (2010), this increase represents a gradual shift in focus from studying early retirement to study labor force participation among individuals aged 6070 years. Most of the empirical contributions focus on this trend in the U.S. labor market but, as shown in Section 3, a trend towards higher labor force participation after the normal retirement age is observed also in a number of other countries.

Munnell and Sass (2008) is a broad analysis of later retirement as a way to solve the financial problems facing the U.S. social security program. Obviously, later retirement might in general be a way to adapt to the demographic challenges facing most OECD countries. Munnell and Sass (2008) include health prospects, older workers' supply 
decisions, and the challenge on the demand side related to an increasing number of older workers along with a discussion of policy options. Another more general approach to meet the demographic challenge through working longer is found in Maestas and Zizzimopolous (2010). The starting point in this paper is the observed reversal in older individuals' labor force participation. Maestas and Zizzimopolous (2010) discuss this new trend in relation to a number of possible explanatory factors: secular changes in the skill composition of the labor force, technological change removing the very physically demanding jobs along with changes in the incentive structure inherent in the social security programs and in employer provided pensions.

Another more general approach is found in Maestas (2010) with focus on so-called "unretirement" in the U.S. labor market, implying a process of exit from the former job to a period of full retirement followed by a return to the labor force. Maestas (2010) finds that men are more likely to unretire than women and that unretirement is similar to partial retirement in many respects except from the fact that those unretiring are more likely to change occupation. Maestas (2010) argues that unretirement could either reflect unexpected financial or health changes or an earlier post-retirement plan.

Pettersson (2011) studies unretirement using Swedish register based data for the period 1994-2007. He focuses on already retired individuals aged at least 55 years. He measures unretirement by the number of retirees having an income from work and finds that the propensity to unretire varies between 6 and 14 percent. The propensity varies significantly with individual background factors. In contrast to younger retirees, older retirees' unretirement seems to reflect a life style rather than a reaction to financial necessity.

In a recent study of unretirement in England, Kanabar (2012) uses a balanced sample of respondents reporting themselves to be retired in Wave 1 of the English Longitudinal Study of Ageing (ELSA). For the first 4 waves of ELSA, Kanabar finds unretirement rates of 5.11 percent for men and 2.70 percent for women. In the estimations for men, Kanabar finds four factors affecting unretirement, namely having a wife in the labor force, education, having a longer financial planning horizon, and experiencing a 25 percent unanticipated negative debt shock between the two last waves of ELSA.

In Kim and Feldman (2000), the topic is bridge employment, a job between a fulltime position and permanent withdrawal from the workforce. Among other things, their results suggest that accepting a bridge employment is positively associated with excellent health, organizational tenure, and having a working spouse and dependent children, while it is negatively related to age and salary.

A number of U.S. studies focus on the trend in older individuals' labor force participation. Haider and Loughran (2001) focus on employed individuals aged 65 or above. Employment in this age group correlates positively with health, education and wealth. Further, this group works for low wages relative to both younger people and to their own previous wages suggesting that non-pecuniary factors are also important.

Using the Health and Retirement Survey, Williamson and McNamara (2001) analyze the determinants of labor force participation beyond the typical age of retirement in the U.S. They focus on gender, age and race on the supply side and point to the need of demand side flexibility regarding part-time work and other flexible routes to retirement. Friedberg (2007) focuses on the declining labor force participation rate until the 
mid-1990s, followed by a leveling off and a trend upwards for older workers in more recent years. As potential explanations of this profile, she points to changes in social security program incentives, in employer provided pensions and in health care.

Johnson et al. (2007) analyze expected future demand in the U.S. labor market along with changes in the nature of work. Based on this, their expectations of future employability of older workers are positive. Gendell (2008) and Shattuck (2010) both focus on recent developments in the U.S. labor market where employment increases for men 65 years and older, with nearly half of them being employed in full time jobs. However, both find stronger increases for women in relative terms, in particular for women with a college education. Finally, Toossi (2009) analyzes the expected growth in the U.S. labor force. In spite of the increased participation in the 65+ group, a decline is expected - not in the labor force - but in the growth rate of the labor force.

Only few empirical studies of recent changes in older individuals' labor force participation focus on labor markets outside the U.S. Klevmarken (2010) is a very comprehensive study of work activity among individuals above the age of 65 in Sweden supplemented with a cross country study based on SHARE data. McNair (2006) is another survey based study focusing on Britain. Among others, the findings of these papers are that the 50+ group in the labor force generally show positive attitudes to work but that a gradual polarization is present in the labor market at an increasing age. Suggested policies to delay retirement include continued training also for older workers and a better understanding of the diversity of older workers. Stenberg et al. (2012) however, do not find any impact of adult education on the age of retirement.

Komp et al. (2010) is another empirical study using SHARE data to study 60-70-yearolds' propensity to engage in paid work in 11 European countries in 2005. This propensity is found to be especially high in Denmark, Sweden and Switzerland and especially low in Belgium and France, reflecting among other things early retirement program differences. One main result is that occupational prestige - as one element of socioeconomic status has a significant positive impact on this propensity. However, interacting occupational prestige with the relative importance of private pensions, Komp et al. (2010) find a negative impact.

Anxo et al. (2012) contains a study of the development in 50-74-year-olds' labor force attachment in 8 European countries. The emphasis in the study is on socioeconomic factors in relation to longer working lives rather than on the impact on fiscal sustainability. Eurofound (2012) presents results from a survey motivated by the remarkable increase in work after retirement in the EU, especially during a period with decreasing employment rates in general. The study points to the great variation in the phenomenon, i.e. at least 20 percent of retirees working work due to financial needs as a reaction to the financial crisis while at least 60 percent work with non-pecuniary motives as the main driving force.

In a survey based study mainly of Dutch employers, Dalen et al. (2010) shift the focus to the demand side of older workers' paid work. To adapt to an ageing workforce, size of the organization is found to be an important variable. However, at the time of the survey many Dutch firms seem to have a personnel policy with "opposite" age discrimination, i.e. a policy increasing older workers' effective wage in economic terms. Very few firms seem to follow policies designed to match productivity and wages better over the life cycle of workers. 


\section{Recent international trends in labor market activity at older ages}

The demographic challenge is found in most OECD countries to varying degrees. In this section, we look briefly into whether there seems to be any adjustment to this challenge by considering whether early retirement is countered to or reinforced by labor market activity at older ages. To this end, we examine the trends in employment rates for 60-69-year-olds in a number of selected OECD countries in the years since 1990.

We focus on men as employment rates for women are more or less affected by cohort effects in many OECD countries, se Figures 1 and 2. In Figure 1a we show employment rates from 1990 to 2011 for men 60-64 years old in the G7 countries. The first impression from Figure 1a is the very big cross country variation in the level ranging from 10-20 percent in France to 70 percent in Japan. For Italy and Japan the level is stationary, around 30 and 70 percent respectively. For the remaining five countries employment rates are increasing from the mid-1990s and on. The most impressive increases are found for Australia and Germany where employment rates increase by 20 percentage points, in Germany over a period of only 10 years. To illustrate the big cross country differences, we show the changes in employment rates in percentage points from 1995 to 2011 for 60-64 years old men in all OECD countries, see Figure 1b. The range is from a 30 percentage points increase in New Zealand to a 14 percentage points decline in Turkey. However, the unweighted average change is an increase of 6.9 percentage points.

Figure 2a shows the employment rates for 65-69 years old in the G7 countries since 1990. Here, too, the dominant profile is increasing employment rates especially in the most recent 10-15 years, most pronounced in Australia. The range in the 2011 level is impressive, i.e. between 5 percent in France and 47 percent in Japan.

The change across all OECD countries from 1995 is shown in Figure 2b. As in Figure $1 \mathrm{~b}$ the range is impressive, i.e. between an increase of 17 percentage points in New Zealand and a decline of 9 percentage points in Iceland. The unweighted average change is an increase of 3.2 percentage points from 1995 to 2011.

As expected, employment rates increase even faster for women than for men, presumably due to strong cohort effects. For the 60-64 years old, the range in the change in employment rates from 1995 to 2011 is between an increase of 36 percentage points and a decline of 8 percentage points. The unweighted average change is an increase of 10.8 percentage points. The corresponding range for women 65-69 years old is between an increase of 24 percentage points and a decline of 14 percentage points ${ }^{1}$.

The overall conclusion from these recent international trends seems to be that working more in the $60+$ group is a relevant contribution to reduce the pressure from population ageing. Hence, the trend until recently toward early retirement has been countered by increases in both the average effective age of retirement and the labor market activity beyond age 60. In the next section we describe recent Danish trends in this area in more details.

\section{Trends in Denmark in recent decades}

In this section, we first outline the policy setting around retirement and next, we describe paid work after age 60 in Denmark. 
a

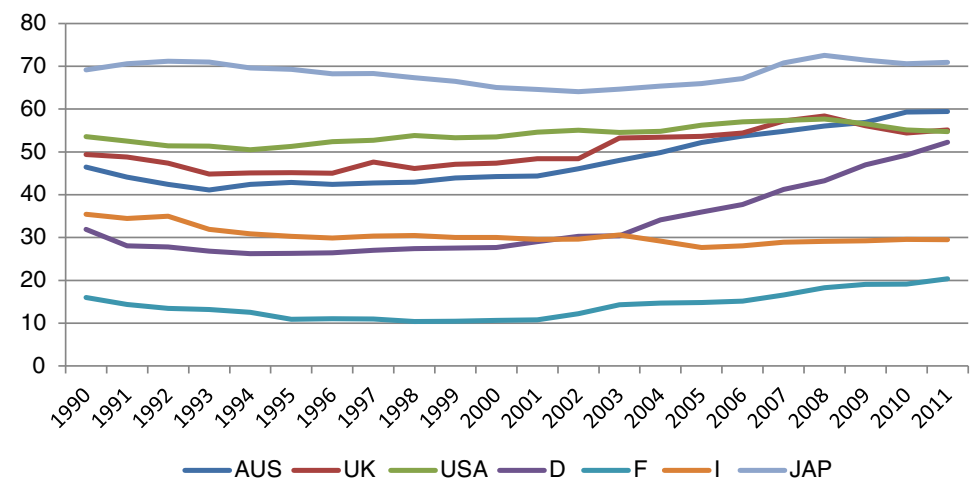

$\mathrm{b}$

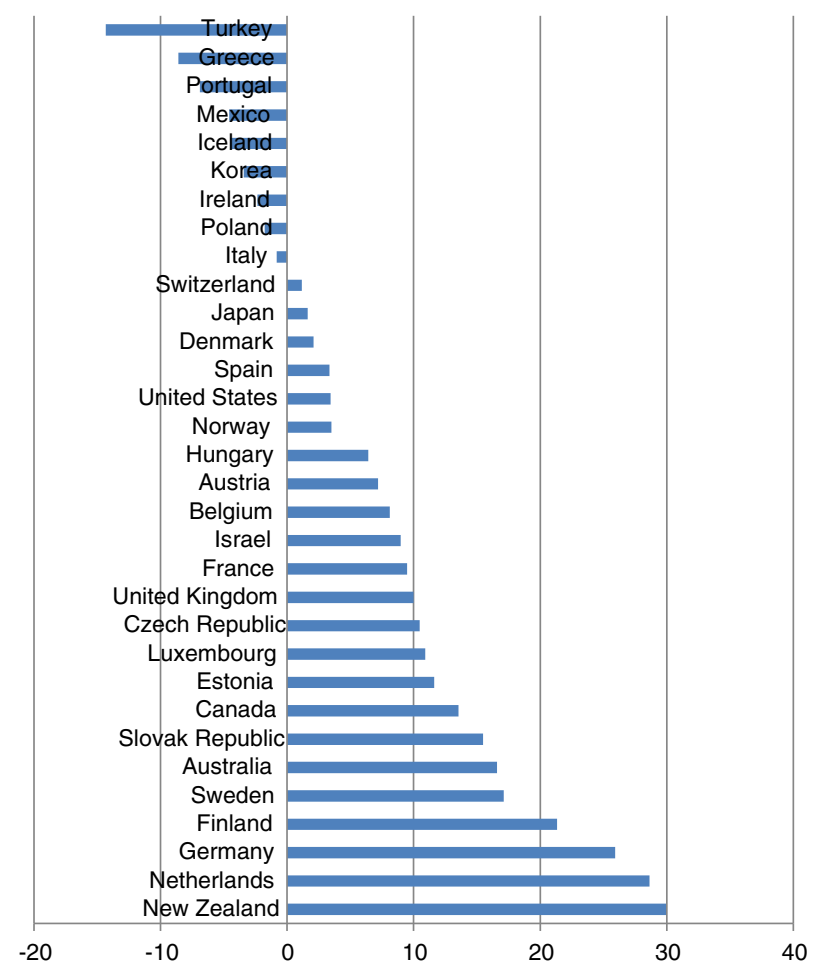

Figure 1 Employment rates, men, 60-64 years. a. levels, G7 countries, 1990-2011, b. changes, OECD countries, 1995-2011, percentage points. Source: OECD (2013).

\subsection{Policy setting}

The main retirement program in Denmark in the area of Social Security is Old Age Pension (OAP), a PAYG program for which everybody is eligible from age $65^{2}$. The other main program is Social Disability Pension (SDP). Depending on visitation on medical and/or social criteria this program is open for everybody aged 18-64 years. The main program for early retirement is the so-called Post Employment Wage (PEW) which was introduced in 1979. Since then, a number of policy changes has tightening access to the program. Conditional on a sufficient long membership in an Unemployment Insurance fund and on being in the labor force at age 59, people aged 60-64 are eligible for the program ${ }^{3}$. Entry can occur at any age from 60 but early retirement benefits are 
a
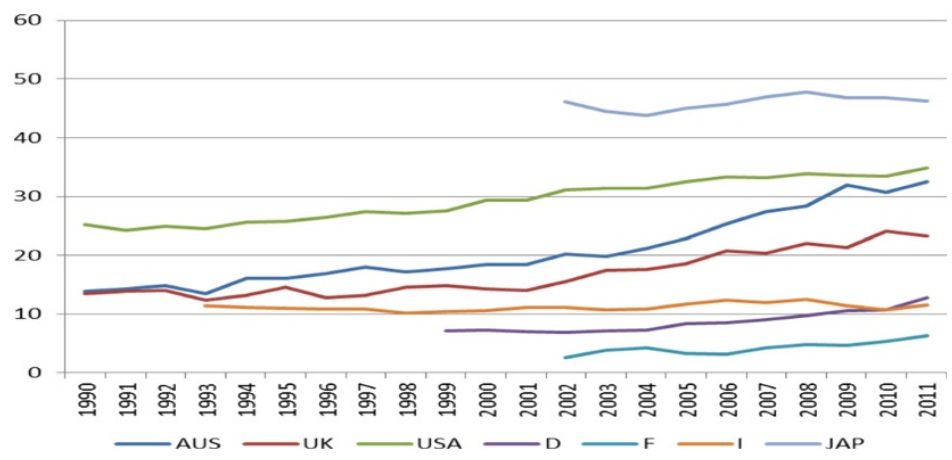

b

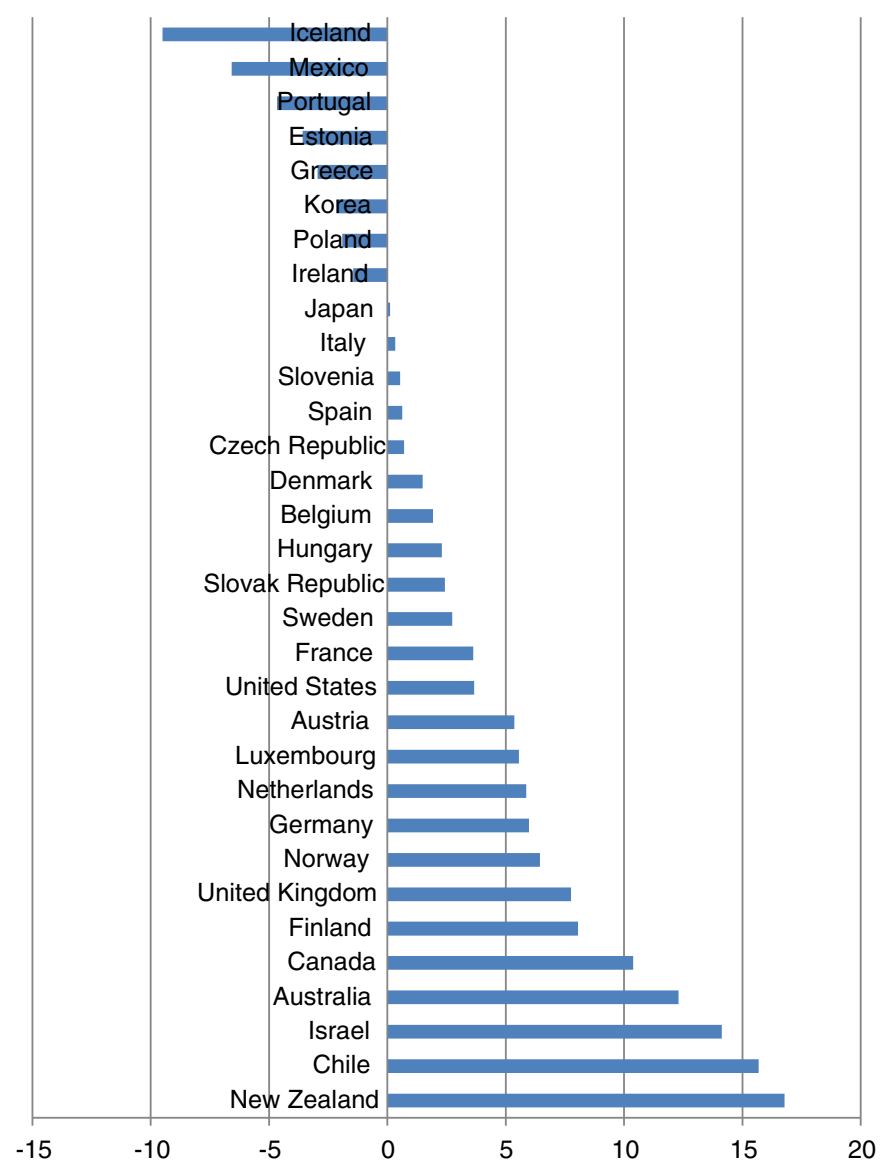

Figure 2 Employment rates, men, 65-69 years. a. levels, G7 countries, 1990-2011, b. changes, OECD countries, 1995-2011, percentage points Percentage points. Source: OECD (2013).

higher if entry is postponed to at least age $62^{4}$. A reform in 1999 introduced a large degree of flexibility in the rules for working while being in the program, i.e. working for pay in a specific number of hours simply results in a proportional reduction in PEW benefits. Finally, since 1999 individuals eligible for PEW, who do not enter the program, accumulates a tax rebate for each quarter they remain in the labor force until age 65.

In recent years, policy changes have been implemented to increase incentives to work beyond 65 and to reduce or dismantle barriers for continued work. Work beyond 65 
can take many forms, i.e. continue in present job - or in another - either full time or part time job, or in a bridge job between former job and full retirement. Today, it is possible to delay take up of OAP on actuarial conditions until age 75 conditional on having a minimum of 1000 hours of work annually. Further, means testing of supplementary OAP against income from work has been reduced. Take up of labor market and private pensions can - with actuarial adjustment - be delayed until age 75 and certain groups of public sector employees have no longer mandatory retirement.

In this section we use administrative register data to look into whether these policy changes along with trends in cohort health and education have had an impact on labor market activity indicators beyond age 60 in Denmark. We look first at indicators of the extent of labor force participation and employment in the $60+$ age groups. This is followed by descriptive indicators of the share of individuals with positive earnings from work. This is further supplemented by looking at indicators of take-up of the most popular early retirement program, the PEW program. Finally, we look into the change over time in the effective average retirement age for people coming from the labor force and on indicators for continued labor market activity after entry to an early retirement program and after having passed the age for potential eligibility for OAP respectively.

\subsection{Labor force participation and retirement among older workers}

For individuals aged 60 years and older, Figures 3 (men) and 4 (women) show the labor force participation rates since 1981 . The age group 60-64 years old is potentially eligible for PEW (and other early retirement programs) throughout the period. It is evident that the introduction of PEW from 1979 resulted in a very strong decline in labor force participation for both men and women. The decline for men is from initially about 60 percent to about 40 percent 20 years later. The corresponding figures for women are 31 and 23 percent respectively. It is equally evident that labor force participation begins increasing from the late 1990s and by the end of the period the level has nearly returned to the prePEW level - an increase that is most pronounced for women. This shift coincides with the major reform of PEW enacted from 1999. However, other factors like cohort effects, and changing educational levels may also have an impact, cf. below.

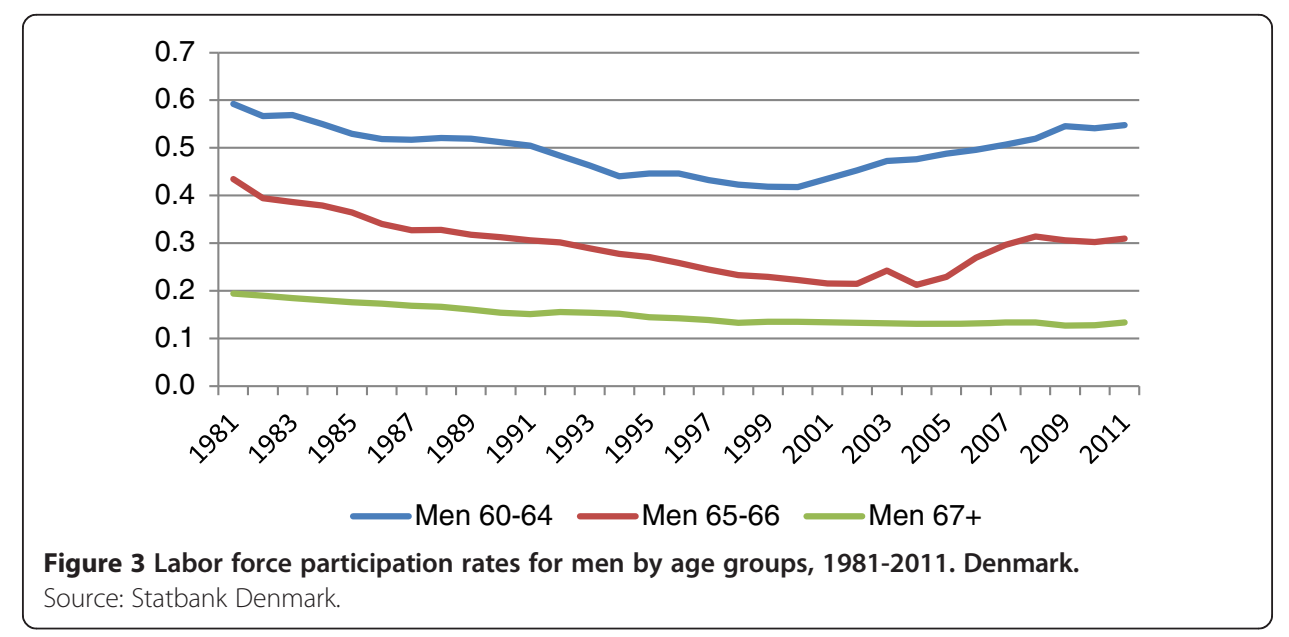




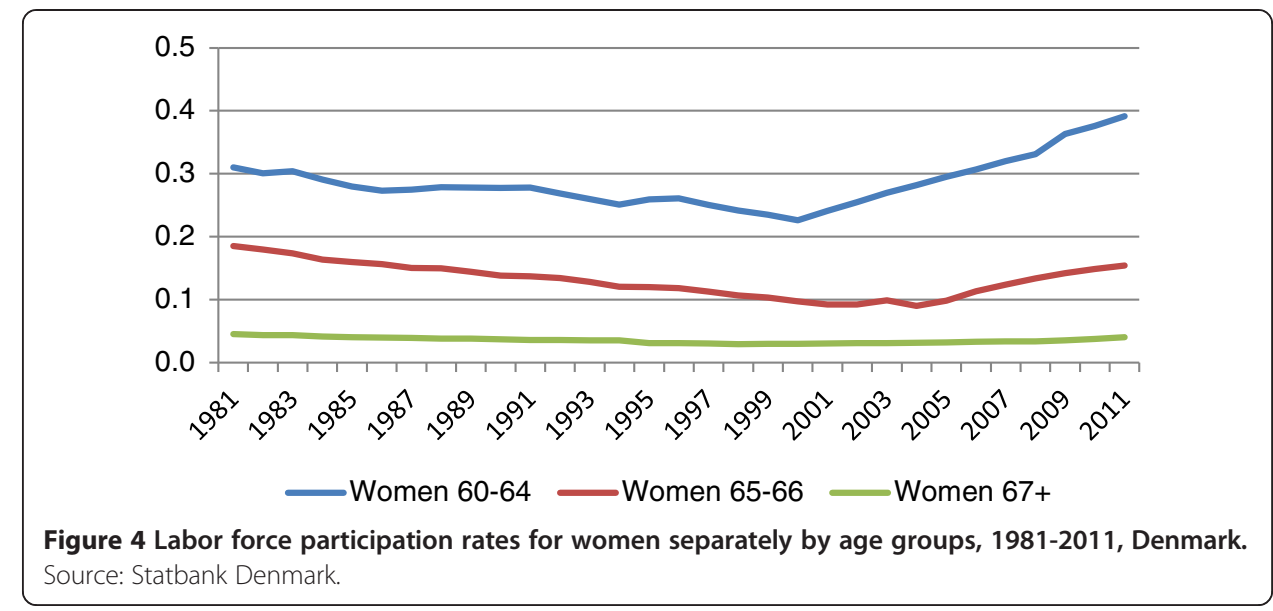

The 65-66 years old follow the same profile as the 60-64 -year-olds but at a lower level and with the turning point coming a few years later. Until 2003 this age group was eligible for PEW on the same terms as the 60-64 years old. A policy reform in 1999 changed OAP eligibility from 67 to 65 years for everyone born after June 30, 1939. As a consequence of this, 2004 and 2005 are intermediate years where one, minor, group of the 65-66 years old are still eligible for PEW. The shares remaining in the labor force increase with about 10 and 7 percentage points for men and women respectively, probably reflecting that OAP is significantly less financially attractive than PEW, a fortiori making continued work more attractive.

Another way of illustrating the changes in labor force participation is found in Figure 5 showing the average age at retirement from 1981 to 2009, conditional on being in the labor force in the year before retiring. Thus, people entering a retirement program from a state outside the labor force are excluded in the calculation behind Figure $5^{5}$. The profiles in Figure 5 shown separately for women and men are dominated by program innovations and reforms while the business cycle seems to have much less of an impact. The average age at retirement from the labor force declined with more than a year from the introduction of the PEW program in 1979 until a new stationary level from the mid-1990s. From about 1995 to about 2004 the average age remains stable followed by a strong increase during the rest

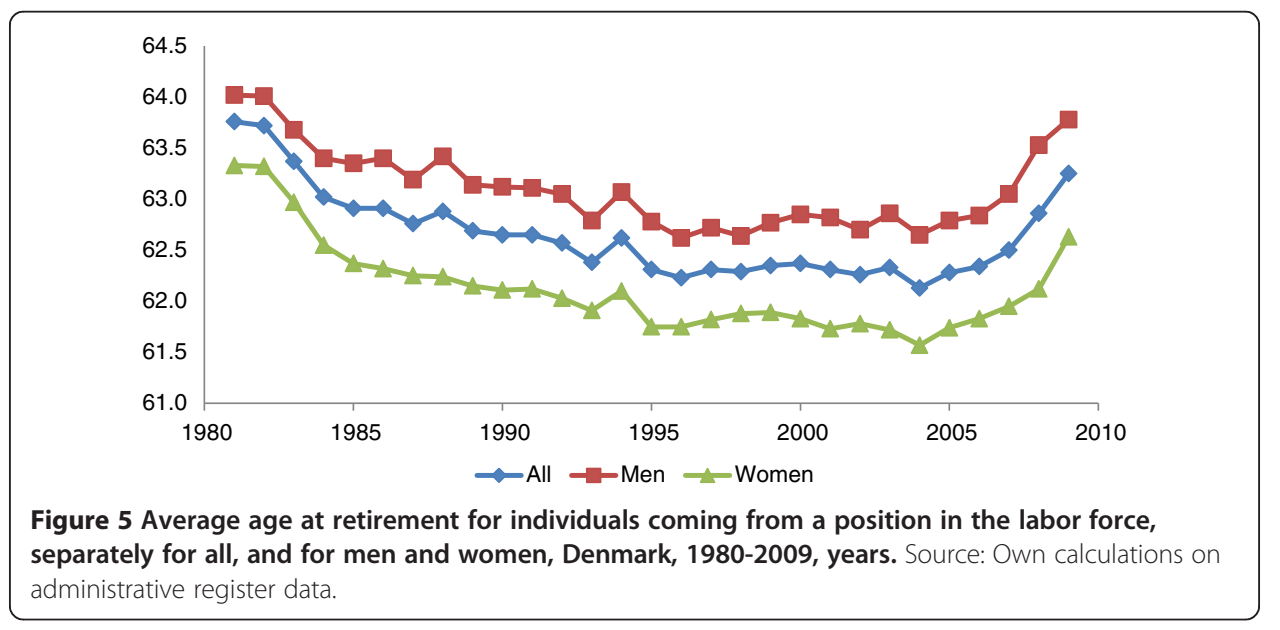


of the period corresponding to the increase in labor force participation. During the whole period, the trend in the average age is parallel for men and women. In most years, the average age is about one year higher for men than for women.

The increasing labor force participation in the 60 and older group can obviously be the outcome of several interacting factors. Policy reform is one possible factor. For those aged 60-64(66) years policy changes might have an impact on the take-up of PEW early retirement, and conditional on take-up, increased flexibility for participants in PEW could induce more individuals to take up paid work. Other, more long run trends are cohort factors relating to education and health where increasing levels and improvement over time, respectively, might have an impact on the choice between early retirement and continued work. Finally, the demand side may play a role in explaining the increasing employment rates in the 60+ group, in Denmark as well as in most other OECD countries, cf above.

Figure 6 shows the share taking up the PEW program in the age groups potentially eligible for entry. The interpretation of Figure 6 is a very strong increase in take-up until the peak in 2004 at just above 50 percent. In the period 2006-2011, in which the relevant age group is 60-64 years old, take up is falling for both women and men supporting the profiles of labor force attachment in Figures 3 and 4.

Other factors explaining the profiles in Figures 3 and 4 could as mentioned be cohort changes in educational qualifications and in health potentially affecting the age dependent labor supply. Figure 7 summarizes the very significant increases over the last 20 years in educational qualifications for the 60-64 years old by showing the strong decline in the shares of women and men in the age group without any formal post-school education. Standard results in labor supply and retirement behavior lend support from the profiles in Figure 7 to the increasing participation profiles in Figures 3 and 4.

The profiles in Figures 3 and 4 also find support in the summary change in health measures shown in Figure 8 based on a comprehensive survey of the older Danish population collected every fifth year since 1997. Figure 8 shows the change over the decade 1997 to 2007 in the shares reporting the highest and the lowest levels of health at ages 62,67 and 72 . In spite of a decade being a short period in this respect, the improvement of self-reported health is impressive and therefore, a potential contribution to explain the increase in labor force participation.

Another aspect of labor market participation among the 60-74 years old is presented in Table 1 showing the share in three age intervals 60 and older with positive earnings, respectively positive income from own business, at five points in time since the late

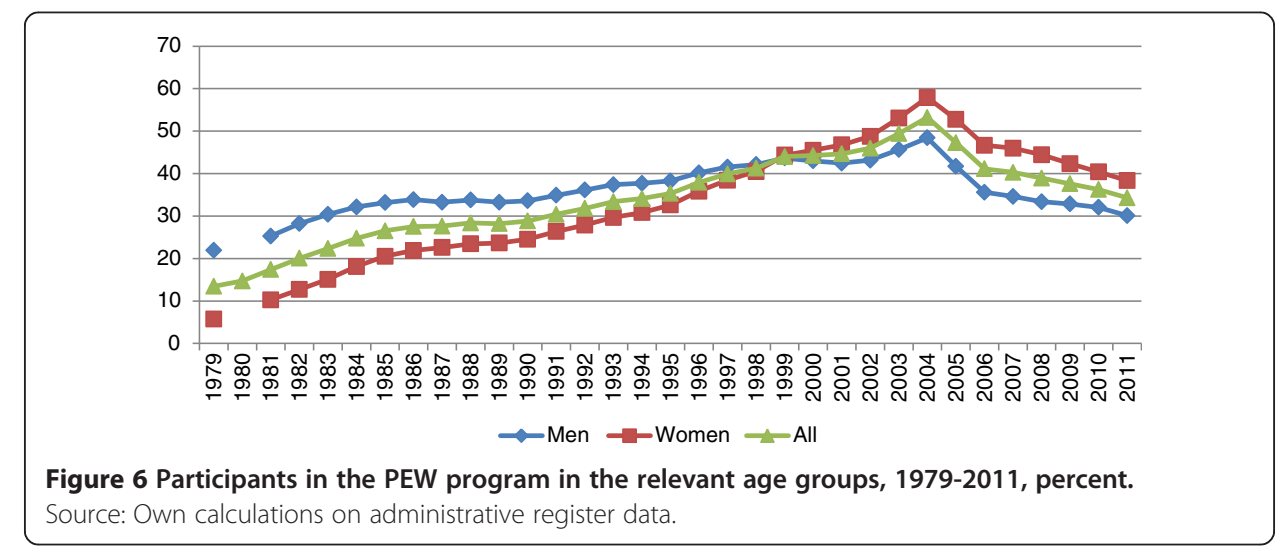




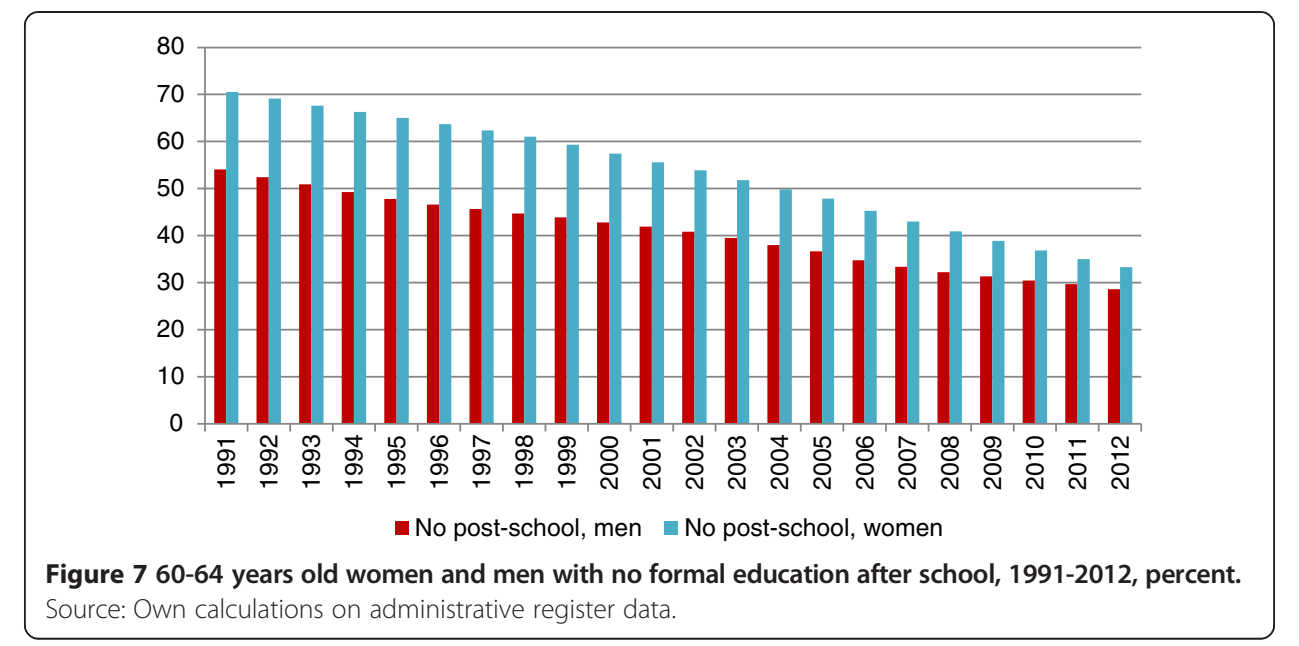

1980s. This is a broader indicator than the one used in Figures 3 and 4 building on minimum levels for market income set by Statistics Denmark for being classified as being in the labor force. It appears from Table 1 that the largest part of the increase in this broader indicator of labor market activity arises from an increase in the share of 60-64 years old with earnings. Hence, the share with positive earnings in this age group goes up from 34 to 43 percent with most of the increase occurring during the most recent 10 years. In the most recent part of the period, a declining fraction in this age group enter PEW, cf. above, and unemployment was low until well into the years with financial crises. For the two older age groups we find small increases in the shares from the late 1990s. The shares in the three age groups with positive income from own businesses are falling throughout the period. It is difficult to identify any cyclical variation in these numbers. Instead, it presumably reflects the long run decreasing share of the labor force with own business.

A major part of the 60-64 years old participate in the PEW program ${ }^{6}$. Throughout the nearly 30 years since introduction of this program, the average age at entry has been fairly stationary. However, the employment profiles in Figure 3 and 4 clearly indicate that take-up of this program has been changing over time. This is illustrated, implicitly, in Figures 9 and 10 showing the share of participants separately for men and women in the PEW program with earnings above different cut-off points in the years $1985-2009^{7}$. The cutoff point is set at $\mathrm{Y}=25,000$ DKK in $2006(3,400$ EURO) and is

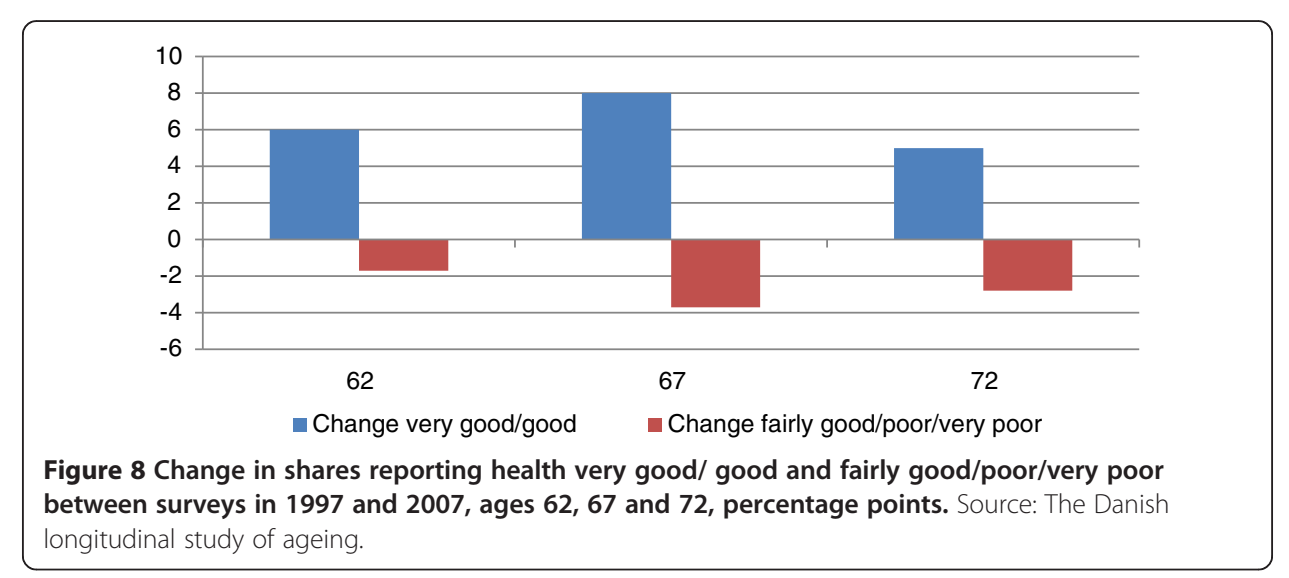


Table 1 Individuals with earnings from work and individuals with positive income from own business by age intervals, percent

\begin{tabular}{lllllll}
\hline & & $\mathbf{1 9 8 9}$ & $\mathbf{1 9 9 4}$ & $\mathbf{1 9 9 9}$ & $\mathbf{2 0 0 4}$ & $\mathbf{2 0 0 9}$ \\
\hline \multirow{3}{*}{ Earnings } & Age & & & & & \\
& $60-64$ & 34.1 & 32.4 & 35.3 & 37.3 & 42.8 \\
& $65-69$ & 15.4 & 14.5 & 15.4 & 17.3 & 17.4 \\
Own business & $70-74$ & 6.3 & 5.9 & 6.1 & 6.8 & 8.3 \\
& $60-64$ & 10.1 & 9.9 & 9.2 & 9.6 & 9.1 \\
& $65-69$ & 7.9 & 7.9 & 7.2 & 6.8 & 6.9 \\
& $70-74$ & 6.3 & 6.0 & 5.5 & 5.2 & 4.8 \\
\hline
\end{tabular}

Source: Own calculations on administrative register data.

adjusted by hourly earnings in manufacturing industry throughout the period included in Figures 9 and $10^{8}$. As a simple sensitivity control we show also the shares with earnings above $0.5 \% \mathrm{Y}$ and above $2 \% \mathrm{Y}$. For men, Figure 9 shows a fairly stationary level around 20 percent for those with earnings above the cutoff point Y. However, the sensitivity control shows an interesting pattern for the most recent years where the stable share at cutoff point $\mathrm{Y}$ is the outcome of a declining share with a marginal attachment to paid work and a corresponding increase in the share with earnings at least at $2 * Y$. For women, we find the same profiles as for men, although at a lower level. A joint conclusion from Figures 6, 9 and 10 is a decline in take up of the program in recent years, and at the same time a higher level of paid work after entry to the program.

Next, we look into whether the trend in the 60-64 years old group also shows up in the older age groups 65-69 and 70-74 years old. As in the results above, we include individuals in the calculations who were in the labor force at age 59 years old. In Figure 11 we show the shares separately for men and women in the two age groups with annual earnings at least corresponding to twice the monthly earnings for full time workers. For men aged 65-69 years, we find a quite impressive increase, in relative terms about 40 percent. The share having earnings at least corresponding to half the cutoff point is slightly above 20 percent. For women in this age group, the share with the cutoff point at $2 \% \mathrm{Y}$ is stable about 6 percent until a quite strong increase from 2007 to 2009.

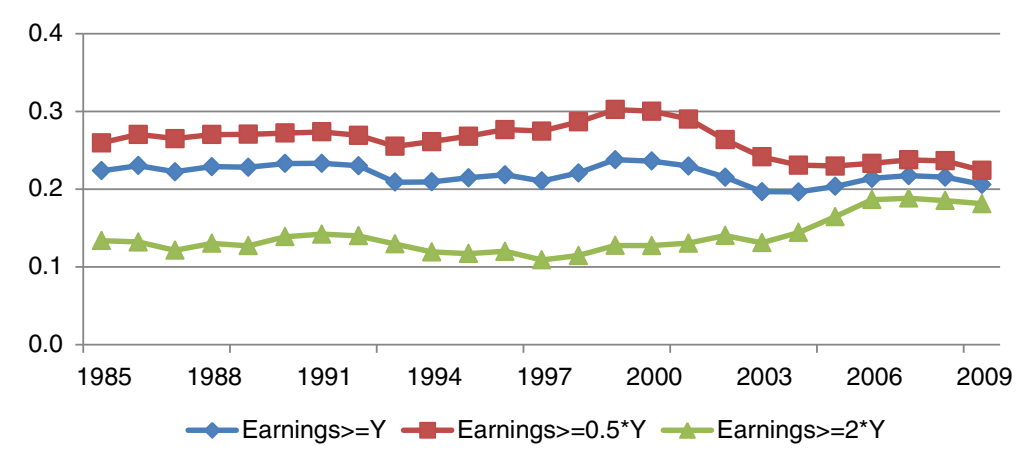

Figure 9 The share of male participants in the PEW program with earnings from work above different cutoff points ( $Y=25,000$ DKK in 2006), 1985-2009. Source: Own calculations on administrative register data. 


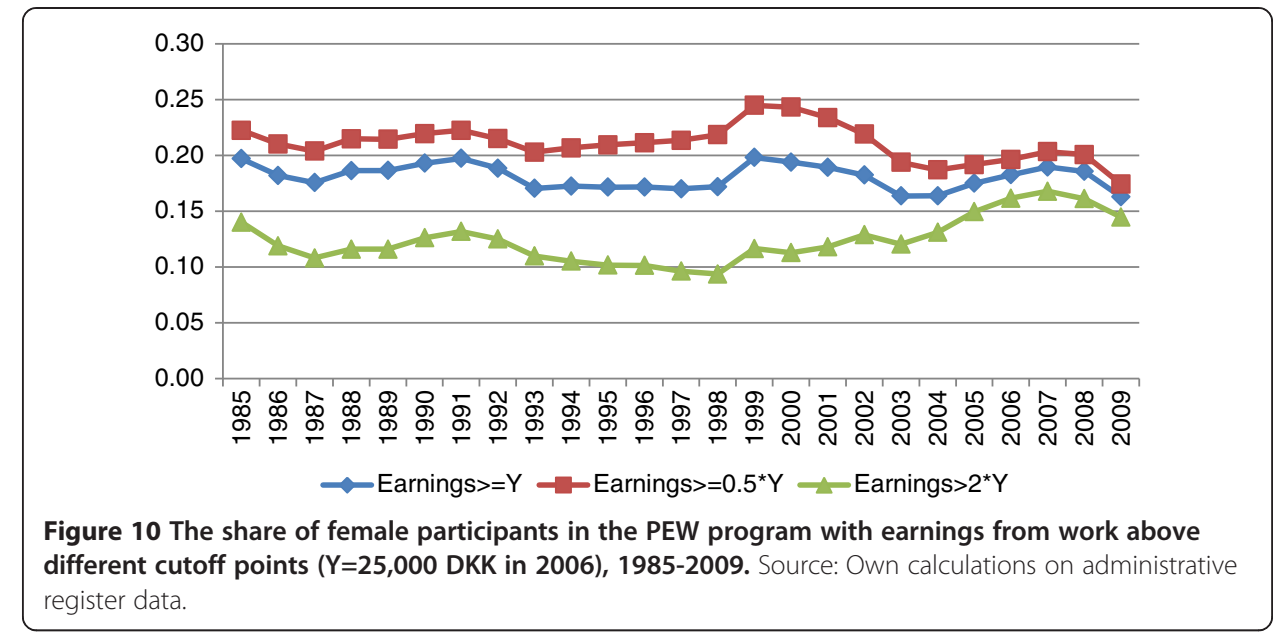

For those 70-74 years old, we find, not surprisingly, a significantly lower level of the share, but in relative terms the same increase as found for the 60-64 years old. For women the share is low, increasing to 2 percent in 2009. Concluding, the increasing labor force participation is found not only for the 60-64 years old, potentially eligible for early retirement, but also for the older $65+$ group.

In Figure 12 we illustrate how the share of people with positive earnings changes in relation to the number of years since exit from the labor force to PEW and to other forms of pension in 1997, respectively. The initial levels differ as expected between 32 percent in the PEW group and 9 percent in the other pension programs group. For both groups, the profile is down to around a quarter of the initial level after 11 years.

A final aspect is illustrated in Figures 13 and 14, again shown for retirement to PEW and to other pension programs respectively. We have selected the birth cohort 1935, who became eligible for PEW from 1995 and for OAP in 2002. For exit to PEW, it is obvious from Figure 13 that late retirement correlates positively with the share having positive earnings. Looking at Figure 14 we find another pattern. Those who retire at the earliest opportunity at age 60 have very little labor market activity after retirement and consequently very little interaction with time after retirement. Those who retire at the OAP age have a steep years after retirement gradient but with an initial level well above those who retired at 60 . About the same gradient is found for the in-between group retiring at age 63 but here at a higher level until the early 70 s.

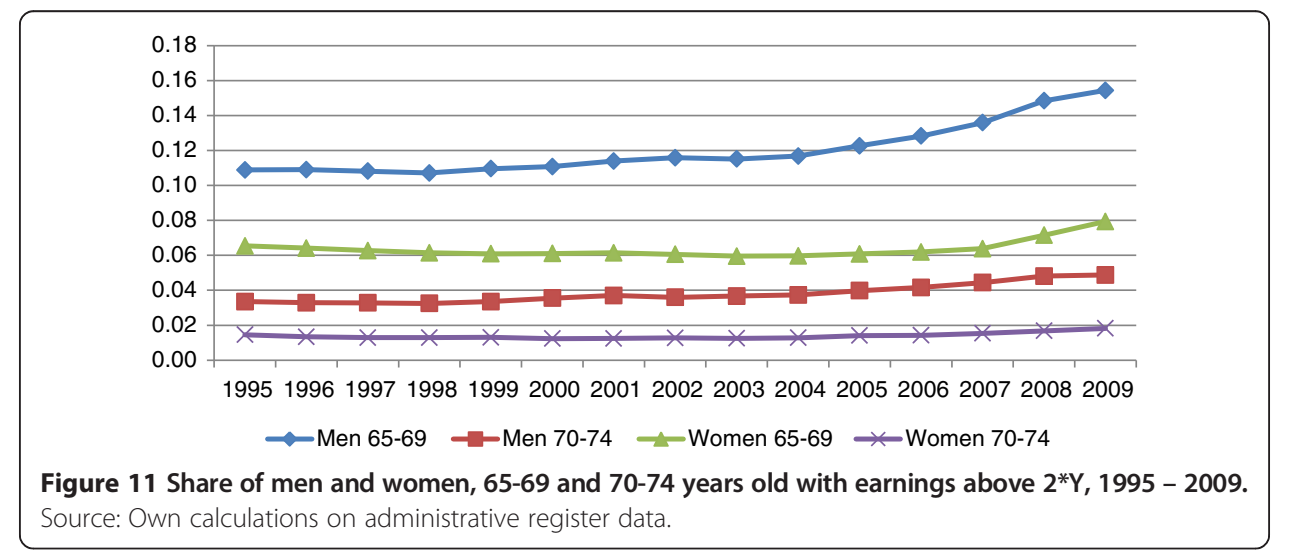




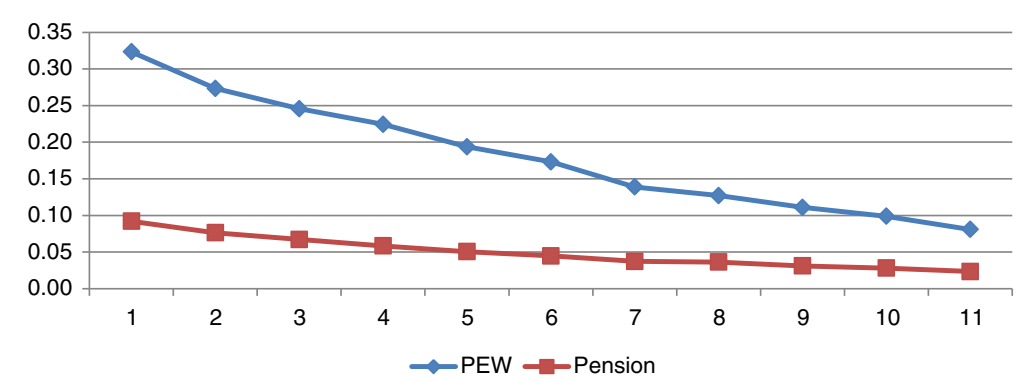

Figure 12 Share of entrants to PEW and pension between 1997 and 1998 with positive earnings in subsequent years. Source: Own calculations on administrative register data.

\section{Characteristics of individuals working after $\mathbf{6 0}$}

In this section, we report results from a number of probit regressions of the probability of having a non-trivial labor market activity after entry to a retirement program. We specify this as having above 25,000 DKK (3400 euro) in earnings from work ${ }^{9}$. In Tables 2 and 3, we show the marginal effects from estimating this probability for the year 2006 separately for people aged 65-74 years, that is individuals who have reached the OAP age, and for people aged 60-64 years who have retired through PEW.

In Table 2, we focus on individuals aged 65-74 years in 2006, who were in the labor force at age 59. For this group, the left hand side variable in Table 2 is set equal to 1 if earnings in 2006 are above 25,000 DKK and 0 otherwise. We include the age of the individual as well as a selection of other explanatory variables and present the results for all and separately for men and women. Looking first at the results jointly for men and women, we find that men have a significantly higher probability of having earnings above 25,000 DKK. In the joint regression, we also find that being married and being owner of your own house or apartment have significant positive coefficients. Further, aggregate unemployment in the year prior to the individual's retirement has a significant negative impact on the probability. The latter result suggests that the labor market situation at retirement has an impact on for instance the availability of "bridge jobs" or other forms of partial retirement. Having paid contributions to labor market pension funds or private pension savings accounts has a positive impact. This might be related to the finding of significant and positive coefficients to education with no post-school education as the reference group. Individuals having their own business may at the

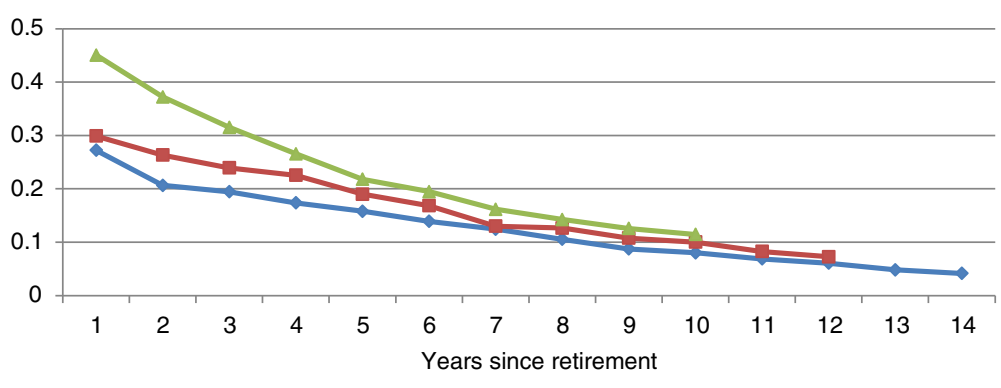

$\multimap$ Exit age $60 \multimap$ Exit age $62 \multimap$ Exit age 64

Figure 13 The share with positive earnings after retirement to PEW by age at retirement and years after retirement, birth cohort 1935. Source: Own calculations on administrative register data. 


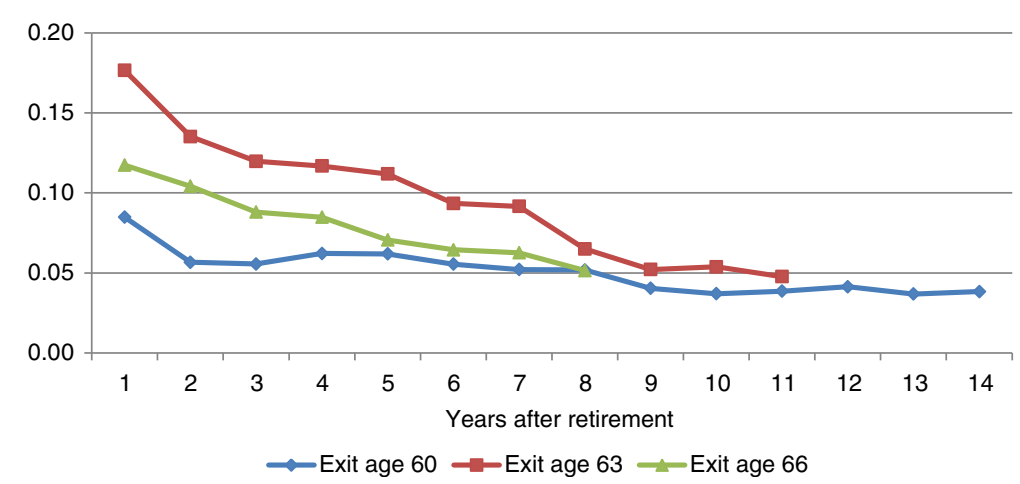

Figure 14 The share with positive earnings after retirement to other pension programs by age at retirement and years after retirement, birth cohort 1935.

same time have an income from earnings. We have included a dummy variable for this group but find a significant negative impact on the probability of having earnings above 25,000 DKK reflecting that having your own business and at the same time working for a wage income are competing activities. The variable "other income", which is the individual income net of earnings from work, is found to have a significant negative impact. Finally, the age coefficients have the expected decreasing profile with age 74 being the reference age.

Table 2 Probit: Marginal effects for having earnings > 25,000 DKK (3400 euro), 2006, 65-74 years old

\begin{tabular}{|c|c|c|c|c|c|c|}
\hline & \multicolumn{2}{|c|}{ All } & \multicolumn{2}{|c|}{ Men } & \multicolumn{2}{|c|}{ Women } \\
\hline & Marg. effect & $Z$ value & Marg. effect & $Z$ value & Marg. effect & $Z$ value \\
\hline Gender & $0.034^{* * *}$ & 38.14 & - & - & - & - \\
\hline Married & $0.006^{* * *}$ & 7.05 & $0.017^{* * *}$ & 10.72 & $-0.003^{* *}$ & -3.04 \\
\hline Owner & $0.013^{* * *}$ & 15.27 & $0.011^{* * *}$ & 7.74 & $0.013^{* * *}$ & 13.49 \\
\hline Other income & $-0.023^{* * *}$ & -8.86 & $-0.0181^{* * *}$ & -5.33 & $-0.066^{* * *}$ & -12.98 \\
\hline Pens_contr. & $0.008^{* * *}$ & 9.20 & $0.011^{* * *}$ & 7.64 & $0.006^{* * *}$ & 6.18 \\
\hline Own bus. & $-0.017^{* * *}$ & -15.81 & $-0.020^{* * *}$ & -11.68 & $-0.016^{* * *}$ & -11.39 \\
\hline U_year_before & $-0.011^{* * *}$ & -44.79 & $-0.013^{* * *}$ & -32.65 & $-0.009^{* * *}$ & -31.21 \\
\hline Short educ & $0.005^{* * *}$ & 5.83 & 0.000 & 0.13 & $0.010^{* * *}$ & 9.99 \\
\hline Medium educ. & $0.004^{* *}$ & 2.88 & 0.004 & 1.68 & $0.007^{* * *}$ & 4.53 \\
\hline Long educ. & $0.034^{* * *}$ & 14.89 & $0.033^{* * *}$ & 10.25 & $0.052^{* * *}$ & 13.14 \\
\hline 65 years & $0.087^{* * *}$ & 26.50 & $0.120^{* * *}$ & 23.17 & $0.049^{* * *}$ & 12.85 \\
\hline 66 years & $0.076^{* * *}$ & 23.59 & $0.102^{* * *}$ & 20.07 & $0.046^{* * *}$ & 12.16 \\
\hline 67 years & $0.065^{* * *}$ & 20.94 & $0.091^{* * *}$ & 18.41 & $0.037^{* * *}$ & 10.17 \\
\hline 68 years & $0.055^{* * *}$ & 17.95 & $0.076^{* * *}$ & 15.70 & $0.032^{* * *}$ & 8.94 \\
\hline 69 years & $0.041^{* * *}$ & 13.96 & $0.059^{* * *}$ & 12.44 & $0.023^{* * *}$ & 6.67 \\
\hline 70 years & $0.033^{* * *}$ & 11.38 & $0.050^{* * *}$ & 10.79 & $0.015^{* * *}$ & 4.45 \\
\hline 71 years & $0.028^{* * *}$ & 9.52 & $0.043^{* * *}$ & 9.20 & $0.011^{* *}$ & 3.47 \\
\hline 72 years & $0.019 * * *$ & 6.73 & $0.029 * * *$ & 6.25 & $0.010^{* *}$ & 2.90 \\
\hline 73 years & $0.010^{* *}$ & 3.37 & $0.013^{* *}$ & 2.83 & 0.006 & 1.89 \\
\hline Pseudo $R^{2}$ & & 0.0805 & & 0.0554 & & 0.0882 \\
\hline No. of obs. & & 302159 & & 163699 & & 138460 \\
\hline
\end{tabular}

Source: Own estimations on administrative register data. Inference: *** $p<0.001 ;{ }^{* *} p<0.01$. 
Table 3 Probit: Marginal effects for having earnings > 25,000 DKK (3400 euro), 2006, 60-64 years old, in retirement program

\begin{tabular}{|c|c|c|c|c|c|c|}
\hline & Al & & $\mathrm{Me}$ & & Won & \\
\hline & Marg. effect & $\overline{Z \text { value }}$ & Marg. effect & $\overline{Z \text { value }}$ & Marg. effect & $\overline{Z \text { value }}$ \\
\hline Gender & $0.054^{* * *}$ & 34.39 & - & - & - & - \\
\hline Married & $-0.008^{* * *}$ & -4.70 & $0.022^{* * *}$ & 7.24 & $-0.037^{* * *}$ & -18.83 \\
\hline Owner & $0.022^{* * *}$ & 14.27 & $0.012^{* * *}$ & 4.26 & $0.025^{* * *}$ & 14.47 \\
\hline Other income & $-0.334^{* * *}$ & -45.25 & $-0.2764^{* * *}$ & -26.80 & $-0.611^{* * *}$ & -47.10 \\
\hline Pens_contr. & $0.020^{* * *}$ & 13.68 & $0.026^{* * *}$ & 10.27 & $0.016^{* * *}$ & 9.71 \\
\hline Own bus. & $-0.048^{* * *}$ & -18.72 & $-0.061^{* * *}$ & -15.23 & $-0.039 * * *$ & -11.66 \\
\hline U_year_before & $0.028^{* * *}$ & 37.23 & $0.030^{* * *}$ & 22.80 & $0.022^{* * *}$ & 27.75 \\
\hline Short educ & $0.017^{* * *}$ & 10.08 & $0.006^{*}$ & 2.00 & $0.027^{* * *}$ & 14.19 \\
\hline Medium educ. & $0.056^{* * *}$ & 20.30 & $0.059^{* * *}$ & 12.44 & $0.071^{* * *}$ & 21.30 \\
\hline Long educ. & $0.159^{* * *}$ & 26.64 & $0.138^{* * *}$ & 16.92 & $0.228^{* * *}$ & 22.56 \\
\hline 60 years & $-0.057^{* * *}$ & -27.59 & $-0.081^{* * *}$ & -22.44 & $-0.028^{* * *}$ & -12.23 \\
\hline 61 years & $-0.045^{* * *}$ & -23.18 & $-0.059^{* * *}$ & -17.99 & $-0.022^{* * *}$ & -9.74 \\
\hline 62 years & $-0.041^{* * *}$ & -21.59 & $-0.057^{* * *}$ & -18.00 & $-0.018^{* * *}$ & -7.96 \\
\hline 63 years & $-0.044^{* * *}$ & -23.10 & $-0.054^{* * *}$ & -17.18 & $-0.027^{* * *}$ & -12.14 \\
\hline No. of obs. & & 151517 & & 72399 & & 79118 \\
\hline$R^{2}$ & & 0.0694 & & 0.0431 & & 0.1006 \\
\hline
\end{tabular}

Source: Own estimations on administrative register data. Inference: *** $p<0.001 ;{ }^{*} p<0.05$.

Looking at the separate regressions for men and women, we find that marital status has opposite effects. While men's probability of having earnings above 25,000 DKK is higher if they are married, the reverse is found for women. The income effect is significantly stronger for women. Overall, the level for the age coefficients is lower for women than for men and the probability is declining faster for women at increasing age. Further, the gradient in education is steeper for women than for men, and for men only a long education is significant relative to having no post-school education.

In Table 3, we show the same battery of marginal effects from probit regressions for the PEW group. In the joint regression, we find again a significant positive coefficient for men. Further, we find the same differences between men and women with respect to being married and to education as found for the pension group in Table 2. As for the 65-74 years old, the negative income effect is significantly stronger for women. The age coefficients indicate that 64 years old in the PEW program have the highest probability of working, presumably reflecting differences in the entry age to PEW. For aggregate unemployment in the year prior to retirement, we find a positive impact, i.e. the opposite of the finding for the 65 and older group probably reflecting a financial need for finding supplementary income after a spell of unemployment before entry. The opposite effect for the 65-74 years old might instead reflect the demand side, i.e. a lack of possibilities for bridge jobs etc. when having a spell of unemployment in the year prior to entry to pension.

Finally, Table 4 presents the marginal effects from a probit estimation of staying in the labor force for the 60-64 years old group consisting of those potentially eligible for the PEW program. Focus is on some of the same background factors as in the preceding tables and on the possible impact from occupations, ranging from top-level managerial work in occupation 1 to non-specified unskilled work in occupation 9. 
Table 4 Probit: Marginal effects for staying in the labor force from 2007 to 2008, 60-64 years old

\begin{tabular}{|c|c|c|c|c|c|c|}
\hline & \multicolumn{2}{|c|}{ All } & \multicolumn{2}{|c|}{ Men } & \multicolumn{2}{|c|}{ Women } \\
\hline & Marg. effect & $Z$ value & Marg. effect & $Z$ value & Marg. effect & $Z$ value \\
\hline Gender & $0.017^{* * *}$ & 5.58 & & & & \\
\hline Married & $-0.022^{* * *}$ & -7.02 & 0.004 & 0.84 & $-0.049^{* * *}$ & -11.13 \\
\hline Owner & $0.013^{* * *}$ & 4.35 & 0.001 & 0.27 & $0.023^{* * *}$ & 5.32 \\
\hline Other income & $-0.059^{* * *}$ & -10.22 & $-0.044^{* * *}$ & -7.44 & $-0.222^{* * *}$ & -11.60 \\
\hline Pens_contr. & $0.011^{* * *}$ & 4.23 & $0.007^{* * *}$ & 2.12 & $0.019^{* * *}$ & 4.49 \\
\hline Short educ & 0.004 & 1.20 & 0.003 & 0.74 & 0.005 & 1.03 \\
\hline Medium educ. & $-0.012^{* * *}$ & -2.52 & -0.002 & -0.31 & $-0.020^{* * *}$ & -2.80 \\
\hline Long educ. & $0.071^{* * *}$ & 11.98 & $0.071^{* * *}$ & 9.69 & $0.073^{* * *}$ & 7.05 \\
\hline Occup1 & $0.028^{* * *}$ & 4.18 & $0.035^{* * *}$ & 4.63 & -0.001 & -0.03 \\
\hline Occup2 & $0.037^{* * *}$ & 7.38 & $0.057^{* * *}$ & 9.06 & -0.006 & -0.66 \\
\hline Occup3 & $0.025^{* * *}$ & 5.76 & $0.029 * * *$ & 5.09 & 0.008 & 1.10 \\
\hline Occup4 & $0.010^{* *}$ & 1.87 & $0.016^{* *}$ & 1.75 & $-0.013^{* *}$ & -1.80 \\
\hline Occup5 & $0.030^{* * *}$ & 5.46 & $0.032^{* * *}$ & 3.42 & 0.009 & 1.24 \\
\hline Occup6 & $-0.109^{* * *}$ & -5.34 & $-0.097^{* * *}$ & -4.60 & $-0.152^{* * *}$ & -2.14 \\
\hline Occup7 & $-0.074^{* * *}$ & -12.41 & $-0.061^{* * *}$ & -9.73 & $-0.107^{* * *}$ & -3.72 \\
\hline Occup8 & $-0.060^{* * *}$ & -9.16 & $-0.042 * * *$ & -5.97 & $-0.134^{* * *}$ & -7.52 \\
\hline Occup 9 & $-0.013^{* *}$ & -2.20 & -0.010 & -1.38 & $-0.023^{* * *}$ & -2.32 \\
\hline No. of obs. & & 101828 & & 60269 & & 41559 \\
\hline$R^{2}$ & & 0.0164 & & 0.0191 & & 0.0176 \\
\hline
\end{tabular}

Source: Own estimations on administrative register data. ${ }^{* *} p<0.001 ;{ }^{* *} p<0.01$.

Results are presented for all, and separately for men and women. Men have a higher probability of staying in the labor force, independently of civil status while married or cohabiting women have a significantly lower probability. The effect from other income is significantly negative and in absolute terms highest for women. For education, we find that only long theoretical education has a positive impact on staying - the level is the same for women and men.

The picture is very clear regarding the importance of occupation. For men, we find a significant positive impact of being in management and all other more highly skilled occupations. No impact is found for women in these occupations. For both men and women, being in less skilled occupations has a significant negative impact on the probability of staying in the labor force, reflecting a corresponding significantly higher probability of entering early retirement.

\section{Conclusion}

In the last 10-15 years, labor force participation has increased in many countries for people aged 60 and older. In most OECD countries, this is a reversal of a long run trend towards lower average retirement ages. Focus in the present paper is on the experience in Denmark in the last quarter of a century with respect to labor force participation in the typical age interval 60-64 years of relevance for early retirement and in the 65-74 years old group consisting of people above the normal retirement age in the main social security program. In an international comparison, Denmark seems to 
follow the general trend since the mid-1990s of increasing labor force participation in the $60+$ group. So far, this trend has been most pronounced among the 60-64-year-olds and among women.

The increasing labor force participation is reflected in an increase of 1.5 years in the average age of entry to a retirement program since the mid-1990s. This increase is most pronounced since 2004 reflecting also a strong decline in the takeup of the dominant program for early retirement, PEW. A major reform of this program was conducted in 1999 with the purpose of creating incentives to delay retirement. More recently, a number of policy changes have been enacted to delay retirement also among the 65-74 years old and to create incentives to continue having paid work after entry to the social security retirement program. The policy changes have been reinforced by a strong secular trend towards higher average education levels in the 60 and older group. Furthermore, self-reported health has improved significantly for people aged 62-72 years since the late 1990s.

Another focus in the study has been on the extent of and the factors behind having income from work in the 60 and older group. One interesting result in this area is the finding of a decline in the take-up of early retirement in the 60-64 years old group and a significant increase in the propensity of having non-trivial earnings from work among those who do enter the program. Since the late 1990s there has been a shift towards higher importance of still higher amounts of non-trivial earnings. For those 65-69 and 70-74 years old respectively, we also find an increasing share since the turn of the century with earnings from work above a trivial level. Further, we find descriptive evidence of how the share of early and normal age retirees with earnings from work depends on age and retirement program.

Regressions on the probability of having earnings above a trivial level after entry to a retirement program point to a number of significant background factors:

- Positive significance relative to being a man, being married, being owner of your own home, having paid contributions to a pension fund, education.

- Age profile: coefficients are decreasing from 65 to 73 years while no clear profile is found for the 60-64 years old.

- In separate regressions by gender, we find that being married has positive significance for men but negative for women. We also find a steeper gradient in the impact from education for women.

- The aggregate unemployment rate in the year prior to retirement has opposite impact on the probability of having paid work after retirement depending on whether entry is to early retirement where the impact is positive or to normal retirement where the impact is negative.

Finally, estimation of the probability of remaining another year in the labor force for individuals 60-64 years old reveals a very clear picture by gender of the importance of occupations for staying in the labor force against entering an early retirement program. For men, managerial and all other more highly skilled occupations increase the probability for remaining another year. For women, being in an unskilled or low-skilled occupation reduces the probability of staying another year. 


\section{Endnotes}

${ }^{1}$ The 14 percentage points decline is found for Iceland reflecting the extremely deep crisis following the financial breakdown. All other OECD countries with data available for this age group have increasing or stable employment rates for women.

${ }^{2}$ For people born before April 1, 1939, the eligible age was 67.

${ }^{3}$ Before the change in the OAP age, PEW was open between ages 60 and 66 .

${ }^{4}$ Entry before 62 implies means testing of benefits against other pension programs.

${ }^{5}$ Figure 5 excludes the impact of a temporary program opened between 1992 and 1996 for long-term unemployed in their fifties.

${ }^{6}$ As mentioned above, until 2004 the age group with conditional eligibility for this program was the 60-66 years old.

7 The first years 1979-1984 of the program are excluded to focus on the years where all potentially eligible cohorts could be in the program for a maximum number of years.

${ }^{8}$ The 2006 value represents the average monthly earnings for full time workers.

9 The cutoff at 25,000 DKK is somewhat arbitrary. The purpose is to include only non-trivial labor force participation in the estimations. Estimations made at cutoff at 12,500 and 50,000 DKK respectively produce qualitatively similar results.

Competing interests

The IZA Journal of European Labor Studies is committed to the IZA Guiding Principles of Research Integrity. The authors declare that they have observed these principles.

\section{Acknowledgements}

We thank the Danish Ministry of Employment for providing financial support. We are grateful for competent research assistance from Katrine Pedersen, Palle Sørensen and Rune Smet. Earlier versions of the paper were presented at the annual conference at The Danish National Centre for Social Research in 2011 and at the Summer Institute in Ageing and Health at NBER, Boston, in 2012. We received very useful comments from the discussant Stephen Jenkins and from other participants at the meetings.

Responsible editor: Alan Barrett.

\section{Author details}

${ }^{1}$ SFI - The Danish National Centre for Social Research, Herluf Trolles Gade 11, Copenhagen K 1052, Denmark. ${ }^{2}$ Department of Economics and Business, Aarhus University, and SFI - The Danish National Centre for Social Research, Herluf Trolles Gade 11, Copenhagen K 1052, Denmark.

Received: 9 August 2013 Accepted: 2 December 2013

Published: 18 Dec 2013

\section{References}

Anxo D, Ericson T, Jolivet A (2012) Working longer in European countries: underestimated and unexpected effects. Int J Manpower 33(6):612-628

Bingley P, Datta Gupta N, Pedersen PJ (2012) Disability programs, health and retirement in Denmark since 1960. In: Wise D (ed) Social security programs and retirement around the world. NBER, Chicago University Press, Health and Disability Insurance

Dalen HPV, Henkens K, Schippers J (2010) How do employers cope with an ageing workforce? Views from employers and employees. Demgr Res 22(32):1015-1036

Eurofound (2012) Income from work after retirement in the EU. Publications Office of the European Union, Luxembourg

Friedberg L (2007) The recent trend towards later retirement. An issue in brief, Center for Retirement Research at Boston College

Gendell M (2008) Older workers: increasing their labor force participation and hours of work. Mon Labor Rev 131(1):41-54

Gruber J, Wise D (1999) Social security and retirement around the world. NBER, University of Chicago Press

Haider S, Loughran D (2001) Elderly labor supply: work or play? Center for Retirement Research at Boston College, WP, Boston 2001-04

Johnson RW, Mermin GBT, Resseger M (2007) Employment at older ages and the changing nature of work. The Urban Institute, Washington 2007-2020

Kanabar R (2012) Unretirement in England: An empirical perspective. Discussion Papers in Economics, The University of York, 12/31

Kim S, Feldman DC (2000) Working in Retirement: The antecedents of bridge employment and its consequences for quality of life in retirement. Acad Manage J 43(6):1195-1210 
Klevmarken A (2010) Vem arbetar efter 65 års ålder? En statistisk analys, Who works after 65? A statistical analysis. Statens Offentliga Utredningar, SOU 2010:85, Stockholm

Komp KT, van Tilburg T, van Groenou MB (2010) Paid work between age 60 and 70 years in Europe: a matter of socio-economic status? Int J Ageing Later Life 5(1):45-75

Larsen M, Pedersen PJ (2008) Pathways to early retirement in Denmark, 1984-2000. The Int J Manpower 29(5):384-409 Maestas N (2010) Back to work: expectations and realizations of work after retirement. J Hum Resour 45(3):718-748

Maestas N, Zissimopoulos J (2010) How longer work lives ease the crunch of population aging. J Econ Perspect 24 (1):139-160

McNair S (2006) How different is the older labour market? Attitudes to work and retirement among older people in Britain. Soc Pol Soc 5(4):485-494

Munnell AH, Sass SA (2008) Working longer: the solution to the retirement income challenge. Brookings Institution Press, Washington, D.C

OECD (2013) OECD. StatExtract, LFS by sex and age. http://stats.oecd.org/Index.aspx?DatasetCode=LFS_SEXAGE_I_R\#

Pettersson J (2011) Instead of Bowling Alone? Unretirement of Old-Age Pensioners. Department of Economics, Working Paper 2011:14, Uppsala University

Shattuck A (2010) Older Americans working more, retiring less. Carsey Institute, Issue Brief, New Hampshire 16 Stenberg A, de Luna X, Vesterlund O (2012) Can adult education delay retirement from the labour market? J Popul Econ 25(2):677-696

Toossi M (2009) Labor force projections to 2018: older workers staying active. Mon Labor Rev, November 2009:30-51 Williamson JB, McNamara TK (2001) Why some workers remain in the labor force beyond the typical age of retirement. Center for Retirement Research at Boston College, WP, Boston 2001-09

10.1186/2193-9012-2-21

Cite this article as: Larsen and Pedersen: To work, to retire - or both? Labor market activity after 60. IZA Journal of European Labor Studies 2013, 2:21

\section{Submit your manuscript to a SpringerOpen ${ }^{\circ}$ journal and benefit from:}

- Convenient online submission

- Rigorous peer review

- Immediate publication on acceptance

- Open access: articles freely available online

- High visibility within the field

- Retaining the copyright to your article

Submit your next manuscript at $\boldsymbol{\nabla}$ springeropen.com 